Studia i Materiały, 1/2017 (23): 7-13

\title{
Co-Living or a "Sandpit" for Future Entrepreneurs. First Experience from Poland
}

\author{
Magdalena Popowska*
}

\begin{abstract}
Nowadays, the Western world seems saturated with the myriad of enhancements for entrepreneurship development. Also, in Eastern European countries we observe a growing number of initiatives at different organizational levels, aiming at accompanying potential future entrepreneurs in their efforts. Meanwhile, there is one novelty, never before offered on the Polish market - the first co-living space, launched in Gdansk. Therefore, this article aims at presenting the idea of $4 C O \mathrm{~s}$ (co-living, co-working, co-habitation, co-development) initiated by a group of young social entrepreneurs from the Tricity as "Clipster" at the end of 2015. For better understanding of the novelty of this venture on the Polish market, the author analyzes similar initiatives worldwide. This paper is also an attempt to assess the challenges and results of this initiative thanks to the qualitative research methods - structured interviews with its first participants and with its leaders. Additionally, the author suggests some improvements and possible future developments of this initiative.
\end{abstract}

Keywords: entrepreneurship, start-up, support, co-working, co-living.

Submitted: 31.08.2016 | Accepted: 20.10.2016

\section{Co-living lub „piaskownica” dla przyszłych przedsiębiorców. Pierwsze doświadczenia z Polski}

Obecnie świat zachodni wydaje się nasycony istniejaca oferta wsparcia dla rozwoju przedsiębiorczości. Również w krajach Europy Wschodniej obserwujemy rosnaca liczbę inicjatyw na różnych szczeblach organizacyjnych, mających na celu towarzyszenie potencjalnym przyszłym przedsiębiorcom w ich wysitkach. Jednak jest jedna, nigdy wcześniej nieoferowana na polskim rynku, nowość - pierwsza, stworzona $w$ Gdańsku, przestrzeń co-living. Niniejszy artykut ma na celu przedstawienie idei 4COs (co-living, co-working, co-habitation, co-development) zainicjowanej przez grupe mtodych przedsiębiorców społecznych z Trójmiasta pod nazwa „Clipster” pod koniec 2015 roku. Dla lepszego zrozumienia nowatorskiego charakteru tego przedsięwzięcia na polskim rynku, autor analizuje podobne inicjatywy na świecie. Artykut jest również próbq oceny wyzwań $i$ wstępnych efektów tej inicjatywy, dzięki metodom jakościowym - wywiadom z pierwszymi uczestnikami oraz liderami projektu. Dodatkowo, autor sugeruje pewne ulepszenia i ewentualne przyszte zmiany w tym przedsięwzięciu.

Słowa kluczowe: przedsiębiorczość, startup, wsparcie, co-working, co-living.

Nadesłany: 31.08.2016 | Zaakceptowany do druku: 20.10.2016

JEL: M13, O31

\footnotetext{
Magdalena Popowska, PhD - Gdańsk University of Technology, Faculty of Management and Economics Mailing address: Gdańsk University of Technology, Faculty of Management and Economics; ul. Narutowicza 11/12, 80-233 Gdańsk; e-mail: mpop@zie.pg.gda.pl.
} 


\section{Introduction}

Entrepreneurship is a complex process involving decision-making under uncertain conditions. The development of new business ideas is one of the most sensitive periods in the entrepreneurship process. The grim reality is that in Europe around $56 \%$ of new businesses, regardless of the industry, do not survive a five-year period (Eurostat, 2016).

Therefore, in the recent years, there has been a proliferation of different assistance initiatives aimed at enhancing the birth, formation, survival and growth rates of small enterprises (Peña, 2004). Additionally, some environments, including incubators, co-working spaces and technology parks, may facilitate knowledge accumulation and in this way equip the founders of start-ups with skills and information much earlier than other individuals, out of a given network. Also, the information flow is wider, faster and permanent thanks to the diversity of participants of incubation programs and their exposure time (Totterman and Sten, 2005; Fang et al., 2010; Campos and Hormiga, 2012).

This paper aims at exploring a new form of assistance initiatives: the co-living space for future entrepreneurs. Such a platform, named Clipster, was created in 2015 in Gdańsk and constitutes the first experiment of this kind in Poland. For better understanding of this new phenomenon, the paper will reveal new labor market trends and propose a review of similar spaces existing in other countries.

Given the subject of the article, the author decided to use qualitative methods, particularly structured interviews, preceded by a wider opinion survey. Therefore, this paper constitutes a kind of an initial appraisal of the still rather short life of Clipster and requires further in-depth longitudinal studies, which the author intends to undertake in the near future.

\section{Co-Working Becomes Co-Living}

The recent recession changed significantly the labor market worldwide, also by increasing the number of unemployed young professionals. Many of them, instead of desperately looking for a new job, joined the world of freelancers, called iPros (independent professionals) in the EU, that constitute a group of flexible and highly skilled self-employed individuals. The growth in the number of iPros in the EU since 2004 has been remarkable. According to the research conducted by Leighton and Brown (2013), numbers have increased by $45 \%$ from just under 6.2 million to 8.9 million in 2013, making them the fastest growing group in the EU labor market. This growth has not been consistent across EU states; however, it has been especially marked in the Netherlands (93\%), Poland (88\%) and France $(85 \%)$. The mentioned research underlines the change in the way work is performed and, in particular, the shift from having a job to working for clients through cooperation rather than competition. iPros appreciate the autonomy and freedom, but - since they operate in fast-moving knowledge areas - they need appropriate support, especially in knowledge gathering. Therefore, following this trend, co-working area infrastructures are a very precious asset and should be seriously considered in the support policies of EU countries.

Another important trend in the labor market is "remote work", which more and more companies are turning to as a way to reduce costs, boost employee productivity, attract and retain top talents, and help employees manage non-work demands (Bell, 2012). According to an article published in Fortune (2015), "remote work continues to trend upward, with 2014 posting a $26 \%$ increase in open remote job postings over 2013”. A telecommuting relationship requires great communication and a shared vision of what success looks like. A research conducted in the US by Bradford S. Bell (2012) emphasizes that although the penetration of remote work is very diversified across companies, there is a need for cultural support and acceptance of this growing phenomenon. Since remote workers run a higher risk of personal and professional isolation, it is important to develop those who lead them and also to ensure a possibility of social exchange with other individuals. According to GUS [Central Statistical Office] data, the number of self-employed in Poland grew by 63000 in 2015, and now this employment model is practiced by nearly $1 / 5$ of the entire economically active population, and it embraces representatives of various industries, including: consulting, marketing, graphic designers, programmers, architects or people involved in coaching ("Coraz więcej biur", 2015). 
The answers to these growing labor market phenomena of "professional isolation" are numerous, but the most accurate one seems to be the establishment of co-working and co-living spaces. The first solution appeared many years ago, and today the number of co-working spaces continues to increase worldwide (Foertsch, 2015). Forecasts reveal that by the end of 2016 there will be over 10000 co-working spaces worldwide, compared to 7800 in 2015. According to Deskmag Global Co-working Forecast Survey 2016 (Foertsch, 2016), over 60\% of all co-working space owners express the will to expand their facilities. With rising customer expectations, also the quality of such places improves. Residents are free to relocate to a different space that better meets their expectations. So far, only one out of five members plans to move, but the number of "digital nomads" - as they call themselves - is growing. On the other hand, Google trend analysis confirms that the interest of potential customers is on the rise. The Internet search trend for the term "co-working" is constantly growing - it has tripled in the last 5 years (from around $25 \%$ in 2011 to $75 \%$ in 2016), and the most searches for Europe are registered in Spain, Italy and France. Poland is on the eight place, and trend fluctuations are minor. One of the most important examples of co-working spaces are WeWork units existing nowadays in more than 60 locations, providing co-working places to around 40000 people (Tang, 2016). The idea comes from two successful entrepreneurs, Adam Neumann and Miguel McKelvey (the value of their start-up was 16 billion dollars in March 2016), who launched their new project WeLive, a co-living venture, in Wall Street in April 2016. Also, the great tycoons of the facility management business, like Belgian Regus, invested in co-working spaces worldwide, treating this activity as a rising one.

In this particular domain, Poland is not different from other countries - co-working spaces are year by year becoming a very important element of the whole business support network. According to data from the platform Best2Invest (2015), there are 145 offices offering rental desks by the hour in Poland. Most of them are in the Mazowieckie Province, Greater Poland,
Lesser Poland and Pomerania, but we can assume that nowadays this kind of space is available in all Polish cities.

Compared to co-working areas, co-living spaces are a relatively new opportunity for potential entrepreneurs or the iPros society. Apart from delivering a variety of assistance during the daytime, co-living creates an exceptional environment for creative persons, the so-called "digital nomads", twenty-four hours a day. There are already many successful examples of such spaces worldwide. Besides WeLive, operating so far only in the US, one of the inspirations in Europe is Nest situated in Copenhagen, housing a total of 21 entrepreneurs in individual apartments. Nest project managers, Morten Krarup Kristensen and Daniel Jensen, are already looking for new locations, most likely in Paris and Aarhus. Another well-known global co-living provider, but considered "upper-class", is Caravanserai. According to its website, the name alludes to "inclusive palaces along the ancient silk road". Its founder, Bruno Haid, says that "our customer is more the designer from East London, financial columnist, or remote developer from San Francisco" (Tay, 2015), so in reality it is not an offer for young millennial startups. According to its residents, co-living is a lifestyle choice, one that offers a built-in social network and is super-supportive of its members "living the life they want to live". Co-living seems designed to meet the core values of the millennial generation: convenience, community and quality. While co-working and co-living are not without their drawbacks, they will likely be around for the long haul as Millennials continue to put a new spin on the young professional lifestyle (Howe, 2016).

This kind of arrangement, creating special and quite unique environment for iPros and startup founders, twentyfour hours a day, is still rather absent in Poland. To this day, there has been only one co-living initiative, founded in October 2015 in Gdańsk, under the name of Clipster.

\section{Clipster Project in the Startup Ecosystem in Tricity}

The Tricity agglomeration (Gdańsk, Sopot and Gdynia) has become an important hub for the development of 
new technologies and R\&D activities in the last $10-15$ years. This is mainly thanks to the presence of many universities, and in particular Gdańsk University of Technology and University of Gdańsk, but also due to the relatively rich start-up ecosystem including some co-working spaces: $\mathrm{O} 4$ in Olivia Gate, Gdański Inkubator Przedsiębiorczości Starter (Incubator Starter), Startup Zone in the Science and Technology Park in Gdynia, Co-working in the Science and Technology Park in Gdańsk, Academic Incubator of Entrepreneurship and Gdyński Inkubator Przedsiębiorczości. This offer is completed with a few acceleration programs provided among others by Black Pearls VC, Business Link Trójmiasto and Alfabeat team. Recently, the first hackerspace in the Tricity has been created within the Incubator Starter (following similar entities from Warsaw and Wroclaw). All these initiatives and many other activities compete to attract the best and the most motivated future entrepreneurs.

In October 2015, this dense system was expanded to include Clipster, the first co-living space in Poland with 16 miniapartments, situated in a very emergent and convenient district of Gdańsk called Garnizon (the name refers to the old military garrison located there before 1989). This project was launched by a group of young entrepreneurs already involved in startup networks, and in particular in Alfabeat and Starter activities. Clipster was designed as a non-profit activity of a rather social nature with a strong support of local authorities and some private investors, including a local developer. Since the very beginning, this offer has been oriented toward potential startup founders from different countries. However, the internationalization of Clipster activity was of secondary importance. The participation in the project is subject to strict selection criteria aimed at recruiting the best startup projects with huge success perspectives but also giving a chance to the most exceptional originators. Since the price of habitation was set at an acceptable level (from PLN 900 to 1500) comparable to the price of a higher class student accommodation, it was important to make quite restrictive selection rules. A standard length of residence was determined at 3 months, which may be extended till 6 or, if there is a real, evidence-based need, even 9 months.

With Clipster in place, the whole start-up support system may be presented as follows:

Clipster seems to complement the existing offer of incubators with something new that has never existed on the Polish market, namely the place where people - who are very often young and seriously looking for an opportunity to implement their projects - can receive help and assistance 24 hours a day. This is the place where sometimes very immature ideas may be incubated, transformed or completely replaced with something completely different. After leaving Clipster facilities, the best ideas may go through other institutional phases of project development, in particular accelerators (e.g. Alfabeat or Starter). So far, only one project, Machinaroom, has passed to the acceleration phase in the Alfabeat infrastructure (situated in the vicinity of Clipster), but 10 others (out of around 30) received a very positive feedback and are probably looking for further development on their own.

Since October 2015, three rounds of three months each have been organized. During this time, the Clipster project gathered around 30 participants. Beside using the usual co-living and co-working facilities, Clipster residents take part in a large number of trainings and workshops (pitching, business models, stress management, design thinking), cultural events and integration meetings.

Fig. 1. Start-up support system in the Tricity.

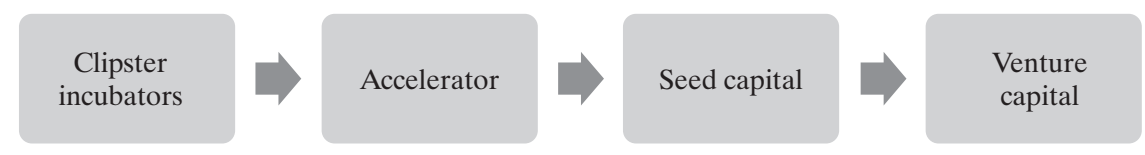

Source: own work based on an interview with Clipster founders. 
All these activities create an exceptional environment, focused on creative networking between the residents themselves and their interaction with coaches and experienced personal mentors. There is no topic limitation for creative ideas: under the guidance of mentors Clipsters design modern solutions in various fields such as medical care, wedding industry, entertainment or e-commerce.

\section{First Experiences from the Perspective of Clipster Founders and Residents}

The author of this article had an opportunity to ask a few questions and also meet some of project participants in JuneJuly 2016. After an initial questionnaire, five cases were selected for further analysis and research: horseshop.pl, Fablab Gdańsk, Wywiad gospodaczy we współczesnym przedsiębiorstwie - konsultacje społeczne, Endlolnsight, and Lassmann Technologies. The selection criteria included: the nature of the project (the author was looking for diversified ideas) and the time spent in Clipster facilities - the author's objective was to get answers from the representatives of all rounds so far recruited from October 2015 until June 2016. At the time of structured interviews, one project (the youngest - horseshop.pl) was at an early idea stage, two at a prototype phase, and two under consultation. As the duration of co-living was different for all respondents, it was obviously impossible to establish that this period was sufficient for a full development of the idea. However, two out of five participants were fully satisfied with the length of their life in Clipster (3 months) with regard to the development of their start-up idea.

Most of Clipster members, including the five analyzed start-ups, had already used some other support programs (incubators, trainings, consulting) or funds (mostly European funding). They found the Clipster offer on the Internet or received it from friends, and they declared having never encountered such a solution before. The recruitment process comprised 3 phases: the first consisted in an on-line application and the two other were individual interviews with the recruitment committee. This body, consisting mainly of Clipster founders, more than for interesting ideas, is looking for interesting people who would bring something to the Clipster community beside benefiting from the co-living and co-working space. Therefore, the committee happened to recruit a person, without any relevant business idea, who was simply hesitating between self-employment and employment and who wanted to experience a freelancer life in a kind of friendly and safe environment. The selection participants are also asked to present their goals for the coming three months of their life in the Clipster space. Their progress plans are then presented officially to the public during an opening event and constitute a basis for further on-going and final assessment/verification process. At the end of the 3 months round, there is another important event, called Mixer, where the most mature ideas are presented to the mixed public for a feedback session. After this presentation, ideas may go either to the acceleration phase, remain in Clipster for three more months or even disappear.

All of the interviewed startups highly evaluated the co-working and co-living possibilities - for them both are the key factors of co-development and progress. The following or similar opinions were frequent in our conversations: "spending time in an environment of people doing something gives motivation to act", "in my opinion the atmosphere of the place is conducive to building trust between participants, and this gives rise to free discussions on any topic". The project participants were underlining the importance of co-habitation, the social life giving them freedom of discussion on their projects with people who are at a similar startup development stage or with those who are more experienced in some more particular fields: coaches, entrepreneurs, mentors. However, a few people affirmed that the intensity of trainings and compulsory participation were detrimental to their ability to concentrate on their ideas. Therefore, they would suggest a better matching of projects with trainings, which would enable a stronger focus on project development. The mentoring system was indicated as the most important and inspiring element of the offer, but also in this part, some improvements were suggested. The mentor's work would require more regularity in project supervision and goal determination. All respondents would recommend - or 
already have - Clipster to others who are looking for assistance, originators, and this independently of the incubation phase of their idea. However, they recognize that the most suitable stage for Clipster support is the one after the incubation phase. Some of the projects (around 25\%) were rejected after a few weeks of assistance - they did not pass the intermediary or final verification process, some residents resigned by themselves (another 25\%).

The founders and managers of Clipster are fully aware of the existing weaknesses and are already working on improvements for Clipster 2, starting in October 2016. They plan to expand current Clipster facilities and maybe, as inquiries arrive from other Polish cities, franchise this activity. From the next round, there will also be a purely technologically oriented path the number of such startups increases al the time, and they require more focus on specific aspects of assistance. Additionally, being already in control of the incubation and acceleration phase, the founders are seeking an opportunity to include the seed phase in the scope of their activity. Since the seed activity requires quite an important investment capacity, they are applying for European funds, in particular using the NCBiR Bridge Alfa envelope.

There is also a summer offer in Clipster: 3-4 days stay with services similar to the usual offer in a kind of "nutshell". This summer (2016), there were above 40 bookings, coming mostly from freelancers (in this case programmers, designers and consultants).

\section{Conclusions}

Trends in the present labor market constantly indicate the need to create space for individual professionals, both those who represent the sphere of services as well as those who want to develop their own business idea. The latter are looking for safe and relatively cheap places that could increase their chances of success. Startups are in fact among the businesses most threatened by the specter of defeat; therefore, a considerable effort is needed at all possible levels (national, regional and local) to increase their chance of survival. The recent shift of co-working toward co-living is gaining on importance month by month. Since co-living creates a unique safe environment, which may be compared to a "sandpit" for the beginning entrepreneurs, it would be interesting to extend this project to other cities in Poland. Unfortunately, it requires an important financial effort; therefore, it needs to be financially supported by the authorities or other decision makers.

Poland continues to be a blank spot on the international map of co-living activity, but this situation may change very shortly due to many factors, including the success story presented in this paper - the Clipster initiative from Gdańsk. Although, the relatively short life of the project does not allow any judgment on its performance and effectiveness, the international successful stories about similar solutions enable us to acknowledge its importance for innovation development at national and international levels. Therefore, we will certainly witness further development and evolution of this concept in Poland in the near future.

\section{References}

Bell, B.S. (2012). Remote work: Examining current trends and organizational practices [electronic version]. Cornell University, School of Industrial and Labor Relations. Retrieved from: http://digitalcommons.ilr.cornell.edu/articles/922 (14.08.2016).

Best2Invest Platform. (2015). Retrieved from: http://www.best2invest.org/main/ (06.08.2016).

Campos, A. and Hormiga, E. (2012). The state of art of knowledge research in entrepreneurship: A ten-year literature review. In: F. Welter, D. Smallbone and A. Van Gils, Entrepreneurial processes in a changing economy, frontiers in European entrepreneurship research (pp. 177-208). ECSB, Edward Elgar.

Coraz więcej biur coworkingowych w Polsce. (2015). Retrieved from: http://biznes.onet.pl/wiadomosci/analizy/analizy-rynku-nieruchomosci/coraz-wiecej-biur-coworkingowych-w-polsce/4s39nl (12.08.2016).

Eurostat. (2016). Business demography statistics. Retrieved from: http://ec.europa.eu/eurostat/statistics-explained/index.php/Business_demography_ statistics (18.12.2016).

Fang, S.-C., Tsai, F.S. and Lin, J.L. (2010). Leveraging tenant-incubator social capital for organizational learning and performance in incubation programme. International Small Business Journal, 28(1), 90-113. Retrieved from: http://dx.doi. org/10.1177/0266242609350853 (16.12.2015).

Foertsch, C. (2015). First results of the new global coworking survey. Deskmag, 20 November. Retrie- 
ved from: http://www.deskmag.com/en/first-results-of-the-new-global-coworking-survey-2015-16 (12.08.2016).

Foertsch, C. (2016). 2016 coworking forecast. Deskmag, 29 January. Retrieved from: http://www. deskmag.com/en/2016-forecast-global-coworking-survey-results.

Howe, N. (2016). Millennials are so happy (living and working) together. Forbes, 14 July. Retrieved from: http://www.forbes.com/sites/ neilhowe/2016/07/14/millennials-are-so-happyliving-and-working-together/\#56e567d11736 (16.10.2016).

Leighton, P. and Brown, P. (2013). Future working: The rise of Europe's independent professionals (iPros). European Forum of Independent Professionals, Professional Contractors Group.

Peña, I. (2004). Business incubation centers and new firms growth in the Basque Country. Small Business Economics, 22(3-4), 223-36.

Regus. Retrieved from: http://www.regus.pl/coworking-space $/$ gdansk gclid $=$ Cj0KEQjwgJq-BRC
FqcLW8_DU9agBEiQAz8Koh9FVkD5yWtAloqjGQ5IPXKlpn7HkSD4HzDkWChghMkaAr9p8P8 HAQ (10.08.2016).

Sutton Fell, S. (2015). Lessons learned from 3 companies that have long embraced remote work. Fortune, 12 February. Retrieved from: http:// fortune.com/2015/02/12/lessons-learned-from-3 companies-that-have-long-embraced-remote-work/ (12.08.2016).

Tang, J. (2016). Being at WeWork: The realities of co-working. Forbes, 28 April. Retrieved from: http://www.forbes.com/sites/jeantang/2016/04/28/ being-at-wework-the-reality-of-coworking-officespace/\#71072ab02e6e (08.08.2016).

Tay, D. (2015). The rise of coliving spaces is bringing digital nomadism to the next level. Retrieved from: https://www.techinasia.com/coliving-spaces-digital-nomads (19.02.2016).

Totterman, H. and Sten, J. (2005). Start-ups: Business incubation and social capital. International Small Business Journal, 23(5), 487-511. 